\title{
Entrepreneurship
}

Jan a Jun $2019-$ v.3 - n.1

ISSN: 2595-4318

This article is also available online at: www.sustenere.co

\section{United States and the transpacific partnership agreement: an analysis of recent dynamics and possible implications for Brazil}

The paper aims to demonstrate the possible impacts after the announcement of the exit of the United States of America from the Transpacific Partnership Agreement (TPP), mainly for Brazil. In view of the above, we work with the hypothesis that the consolidation of TPP can bring great negative impacts to Brazil, since it is out of the agreement and also of most megarregional initiatives. To achieve this, the character work exploratory, uses bibliographical and documentary research from records available in newspapers, articles, magazines, books, films and legal documents. The study shows that the exit of the US from the TPP can positively affect the Brazilian economy, considering mainly the agribusiness sector. Therefore, it is necessary that the country adopts a more proactive international policy that allows to leave the supporting role in the great global economic negotiations.

Palavras-chave: Transpacific Partnership Agreement; Economy; Foreign trade; International politics.

\section{Estados Unidos e o acordo transpacífico de parceria: uma análise das dinâmicas recentes e possíveis implicações para o Brasil}

O artigo tem como objetivo demonstrar os possíveis impactos após o anúncio da saída dos Estados Unidos da América do Transpacific Partnership Agreement (TPP), principalmente para o Brasil. Diante do exposto, trabalhamos com a hipótese de que a consolidação do TPP pode trazer grandes impactos negativos para o Brasil, uma vez que está fora do contrato e também da maioria das iniciativas regionais. Para isso, o trabalho de caráter exploratório utiliza pesquisa bibliográfica e documental a partir de registros disponíveis em jornais, artigos, revistas, livros, filmes e documentos legais. O estudo mostra que a saída dos EUA da UTE pode afetar positivamente a economia brasileira, considerando principalmente o setor de agronegócios. Portanto, é necessário que o país adote uma política internacional mais proativa que permita deixar o papel de apoio nas grandes negociações econômicas globais.

Keywords: Acordo de Parceria Transpacífico; Economia; Comércio exterior; Políticas internacionais.

Topic: Relações Internacionais

Reviewed anonymously in the process of blind peer.
Received: 08/02/2019

Approved: 10/05/2019
Bruna Ellen Reis Becati

Centro Universitário do Sul de Minas, Brasil

brunaellen-bc-@hotmail.com

Sheldon William Silva (id)

Centro Universitário do Sul de Minas, Brasil

http://lattes.cnpq.br/5691436224279198

http://orcid.org/0000-0002-2473-5728

sheldonwilliamsilva@gmail.com

Pedro dos Santos Portugal Junior (it)

Centro Universitário do Sul de Minas, Brasil

http://lattes.cnpq.br/3402598684545658

http://orcid.org/0000-0003-2590-1959

cepi@unis.edu.b

\author{
Lucas Rosa Paiva \\ Centro Universitário do Sul de Minas, Brasil \\ http://lattes.cnpq.br/7560579130730003 \\ lucas@unis.edu.br \\ Gustavo Flausino de Oliveira \\ Centro Universitário do Sul de Minas, Brasi \\ http://lattes.cnpq.br/2355263407944822 \\ cepi@unis.edu.br
}

Referencing this:

BECATI, B. E. R.; SILVA, S. W.; PORTUGAL JUNIOR, P. S.; PAIVA, L. R.; OLIVEIRA, G. F.. United States and the transpacific partnership agreement: an analysis of recent dynamics and possible implications for Brazil. Entrepreneurship, v.3, n.1, p.32-41, 2019. DOI: http://doi.org/10.6008/CBPC2595-4318.2019.001.0005 


\section{INTRODUCTION}

With the advance of the formation of productive processes involving several countries, it is observed a considerable increase of the economic, political and social dependence among the nations. In this sense, it can be said that there is a growth of cross-border flows of goods, services, investments and information. The bilateral trading system seems to be outdated and does not meet the current needs of the market. As a result, a number of countries highly involved in international trade have sought other forms of negotiation than bilateral.

With a focus on issues that deepen multilateral commitments, such as services that were never subject to discipline, labor standards, the environment and e-commerce, the TPP agreement was the first to take this initiative, with twelve countries around the Pacific - States Japan, Canada, Australia, New Zealand, Mexico, Peru, Chile, Malaysia, Singapore, Vietnam and Brunei. These countries account for about $40 \%$ of world trade and this agreement has been discussed with greater recurrence since 2010 (CARNEIRO, 2015).

However, this multinational economic openness is contrary to the policy advocated by Donald Trump, the current US president. Throughout his campaign, Trump focused on securing jobs and boosting national industry. Thus, the proposals of the transpacific agreement are divergent from the proposals of the current government.

This paper aims to demonstrate the possible impacts after the announcement of the exit of the United States of America from the Transpacific Partnership Agreement (TPP), mainly for Brazil. In order to achieve this, exploratory work, to make use of bibliographical and documentary searches from records available in newspapers, articles, magazines, books, photos, films, recordings and legal documents. The TPP proposal is to be the great '21st century agreement' encompassing not only the facilitation of access to goods, services and investment markets, but also a set of new disciplines ranging from regulatory convergence to labor principles and environmental conservation measures.

The TPP can have a major influence on the functioning of the multilateral trading system and may even weaken the role of the World Trade Organization (WTO). In view of the above, we work with the hypothesis that the TPP can bring great negative impacts to Brazil, since it is out of the agreement and also of most megaregional initiatives. Next, the research framework is approached, whose theoretical framework is based on the presentation of the concepts and processes for the formation of trade agreements and economic blocks, as well as a contextualization regarding the TransPacific Association Agreement (TPP).

\section{THEORETICAL REVIEW}

\section{The training of commercial agreements and Economic Blocks}

With the current globalized economy, the commercial trend is the formation of agreements and economic blocs between the interested countries. The purpose of the creation of these blocks is to facilitate trade between member countries, exemption or reduction of taxes or tariffs and seek common solutions to trade problems (GARCIA, 2005). 
According to Rêgo (1996), international trade has as its first trade agreement the General Agreement on Tariffs and Trade (GATT). The agreement was initiated in 1947 and there are more than 100 member nations. A document entitled General Agreement on Tariffs and Trade, which proposed multilateral rules for international trade, was developed with the aim of reducing trade barriers and guaranteeing access more equitable to the markets on their part. Its creators believed that trade cooperation would increase interdependence between countries and help reduce the risks of a new world war. In 1994, following a number of discussions, the round of negotiations containing the latest set of tariff reduction proposals was completed. At that time, the GATT was incorporated by the World Trade Organization (WTO) in 1995.

Within the international context, the WTO is the mainstay of the international trading system. The WTO has basically four functions: to facilitate the implementation, administration, operation and objectives of the agreements of the Uruguay Round; provide a forum for the negotiation of trade relations between member states, with a view to creating or modifying multilateral trade agreements; administer Understanding on rules and procedures relating to dispute settlement; and administering the trade policy review mechanism, which conducts periodic reviews of the Foreign Trade Policies of all WTO members, following policy developments and pointing to issues that are in disagreement with negotiated rules (VALÉRIO, 2009; THORNTON et al., 2014; ALMEIDA, 2016).

Trade relations between countries have been going on for hundreds of years since there is no selfsufficient nation in all sectors that can meet the needs of its entire population and provide some economic development. Therefore, the international commercialization of natural resources, food, energy sources, technology, etc. (SANT'ANNA, 2017) is common and necessary. Subscribe, Baldwin (2013) says that the international agreements aim to create organisms that dynamize the commercial, social and political relations among the member countries. According to the author, these organizations are present in all parts of the planet, acting in the form of economic blocs, countries that discuss the global economy, a body that establishes rules and agreements for international trade, a group of nations that aims to control the production and sale of a particular product, etc..

Chiara (2017) believes that agreements can be provided in various fields, and in particular, in bilateral agreements, they are binding contracts between two parties who accept and agreed to the terms and conditions in relation to something. According to Silva (2013), a bilateral agreement is a type of agreement in which only two parties are involved, and can be signed between states or between a state and an international organization, under the most varied themes such as international trade and security.

In addition, Silva (2016) considers the use of multilateral agreements, signed by three or more subjects of international law, whose main characteristic is the mandatory membership by all its members. Corroborating, Chiara (2017) argues that a multilateral body is a supranational entity formed by several countries, with the aim of reaching global agreements on a particular theme: trade, culture, cooperation or to maintain peace. Other international trade agreements can be reached from nations that aim to integrate economic blocks to flexibilize international trade relations in an attempt to expand the consumer market. 
According to Francisco (2010), the purpose of the agreements is to establish treaties to standardize tax actions in terms of reduction or exemption of taxes on goods and services traded between member countries. Trade between countries that are members of an economic bloc, in theory, increases and generates growth for the countries. According to Pereira (2013), staying out of an economic bloc is living isolated from the commercial world, because every day the trade between economic blocs grows. However, according to the author, the economic blocs are not restricted only to the reduction or abolition of tariffs, they also allow the free movement of people between the countries that make up the agreement.

Dias et al. (2012) consider that economic blocks can be classified according to their characteristics as follows: Free trade area: trade agreements to reduce or eliminate tariffs among member countries of the bloc. Example: North American Free Trade Agreement (NAFTA); Customs Union: in addition to reducing or eliminating trade tariffs between member countries, regulates trade with non-bloc nations through the CET (Common External Tariff).

Example: Common Market of the South (Mercosur); Common Market: also provides for the free movement of capital, services and persons within the bloc. Example: European Union (EU); Economic union: evolution of the common market. Countries adopt the same development policy and a single currency. It is the current stage of the European Union. Taques et al. (2016), consider acriation and the formation of formal economic blocks are not homogeneous, that is, there are different degrees of integration, as shown in figure 1.

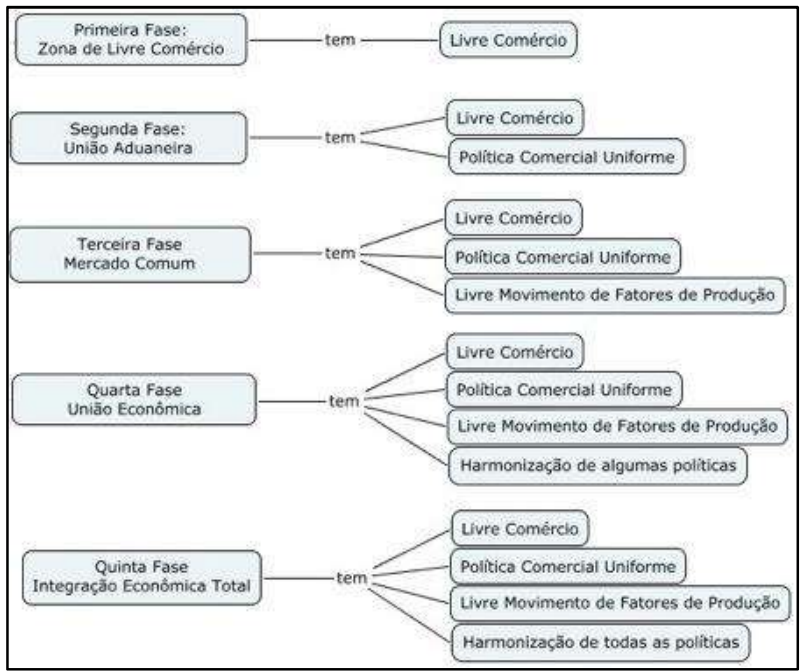

Figure 1: Stages of economic integration. Source: Simões et al. (2002).

The emergence of international economic agreements represents the culmination of a process where different countries can consolidate a real economic space where the dispersed production of goods and services can function without interruption. If successful, these mega-agreements can profoundly alter the governance of international trade (CARNEIRO, 2015). According to Pereira (2013), the number of free trade agreements, counted from its initial effective date, increased from 25 between 1958/1990 and 88 (1991/2000) to 158 during the period According to WTO data. The proliferation of these agreements is interpreted as a 'new wave of regionalism'. 


\section{The Transpacific association agreement (TPP)}

OTPP is a large multinational trade agreement that established free trade between twelve countries in Asia (Japan, Brunei, Malaysia, Singapore and Vietnam), Oceania (Australia and New Zealand), North America (United States, Canada and Mexico) and South America (Peru and Chile). The group brings together three major world powers (the United States, Japan and Canada) and countries that have open, flexible economies that are deeply embedded in world trade, such as some of the Asian Tigers (Malaysia and Singapore) and emerging countries in Latin America, such as Chile and Mexico, according to figure 2 (CARNEIRO, 2015).

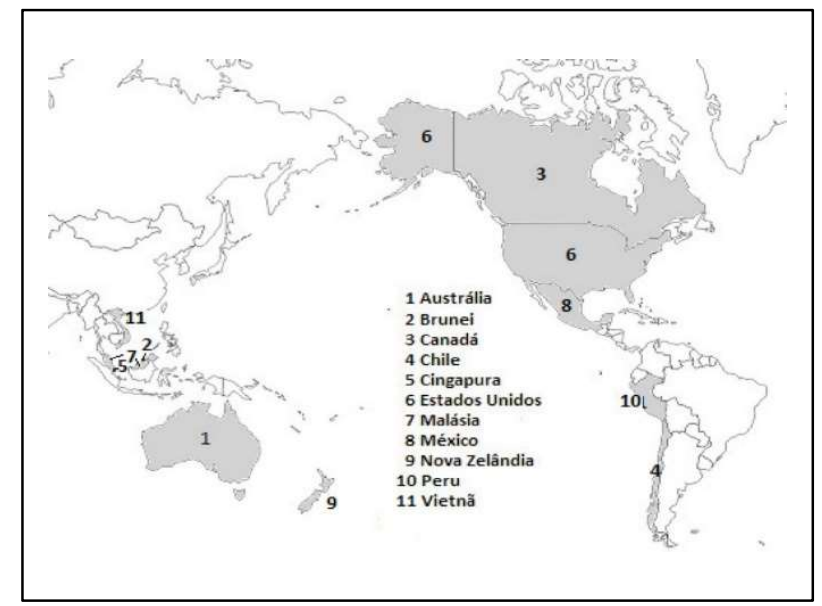

Figure 2: Countries participating in the TransPacific Association Agreement. Source: Lins (2014).

Because of the great economic magnitude of this agreement, it has been considered by many rulers and scholars as the world's largest trade agreement in the 21st century. The TPP can profoundly alter the development of world trade, all participants are members of APEC, and current members have stated that expanding the number of components would likely privilege other members of the organization, in fact the TPP is singled out as one of the possible paths to achieve the goal set by the APEC to achieve, in the future, a free trade area among its members (SANT'ANNA, 2017).

Together, they are believed to account for 40 percent of the world's economy, one-third of all world exports, a consumer market of some 800 million people, and will bring in about US\$223bi a year by 2025 (LINS, 2014; SILVA, 2016). As the TPP is still recent, it is too early to determine what the consequences will be for the countries involved and for world trade, as their success depends on a series of economic, social and environmental measures that are not as simple as are implemented and will depend on the government policies implemented (CARNEIRO, 2015).

For the other countries of the world, the formation of this economic bloc is viewed with some concern in view of the great international economic representativeness of its members, who currently establish relations with several countries that are not part of the treaty. According to Carneiro (2015), a possible consequence would be the reduction of trade relations with countries that are not part of the economic bloc, because, due to the elimination of tariffs and barriers to the movement of goods proposed by the TPP, it will be more advantageous between the agreement countries. 
Because of the great economic magnitude of this agreement, it has been considered by many rulers and scholars as the world's largest trade agreement in the 21st century. The TPP can profoundly alter the development of world trade, since more than a simple trade cooperation agreement, it aims to ensure, among other things, the perspectives outlined in table 1.

Table 1: TPP Sectors and Prospects.

\begin{tabular}{|c|c|}
\hline SECTORS & PROSPECTS \\
\hline Economy & $\begin{array}{l}\text { Economic integration among member countries through the elimination or reduction of tariffs and other } \\
\text { barriers to the movement of goods, services and investments }\end{array}$ \\
\hline Technology & $\begin{array}{l}\text { The establishment of common intellectual property rules for products and technologies that protect } \\
\text { technological innovations in member countries without jeopardizing the scientific development of other } \\
\text { countries }\end{array}$ \\
\hline Work laws & $\begin{array}{l}\text { The standardization of labor laws, thus guaranteeing an increase in labor standards in Asian countries to avoid } \\
\text { the mass migration of companies attracted by cheap labor }\end{array}$ \\
\hline Environment & $\begin{array}{l}\text { The development of common environmental actions that guarantee the sustainable development of the } \\
\text { economies involved in this economic block }\end{array}$ \\
\hline Investment & $\begin{array}{l}\text { The increase of the internal investments of the block that favors the economic development of the countries } \\
\text { and increase the economic integration between them. }\end{array}$ \\
\hline
\end{tabular}

As this agreement affects several sectors of the economy of the countries involved, it took almost 10 years of secret negotiations between the member countries of the bloc to arrive at the document that legitimized it, signed on February 4, 2016. The concept of a (PACS) or Pacific Four (P4) by New Zealand, Chile, Singapore and Brunei (SANT'ANNA, 2017). In this sense, Carneiro (2015) considers that the focus should be on harmonizing technical, sanitary and phytosanitary regulations - including, for example, food safety standards - and simplifying certification procedures and compliance testing.

According to the United States Trade Representative (USTR) disclosure on the progress of the TPP negotiations, 14 member countries discuss the inclusion of chapters on labor issues and protection of the environment. This objective is in line with the position defended by the United States, based on a bipartisan agreement signed in May 2007 by congressmen from that country, which stipulates the guidelines that should guide the negotiation of trade agreements by the Executive Branch.

Environmental protection is also a priority topic for the United States in trade negotiations under the May 2007 agreement that requires US negotiators to seek to incorporate into the FTAs a list of multilateral environmental agreements (USTR, 2007). There is a relative consensus among member countries on the need to include a chapter on the subject, which includes commitments to protect the environment and facilitate trade in goods and services that contribute to this end; however, when negotiations move into the field of specific obligations, especially the possibility of bringing such commitments to dispute settlement mechanisms, negotiations face considerable difficulties (SCHOTT et al., 2013).

As the USTR (2011) puts it, the objective of the chapter on competition is to promote a competitive business environment, protect consumers and ensure a level playing field for member-country enterprises, and negotiations have already advanced to establish commitments and enforcement of competition laws and defense agencies, as well as measures to ensure transparency and protect consumers. Also, according to the document, the TPP will contain a chapter to ensure the operation of electronic commerce, disciplining impediments to its use by consumers and suppliers. 
Such measures already form part of some of the most recent FTAs signed by the United States, such as the agreement with South Korea, which prohibits the application of tariffs on digital products, prohibits the imposition of 'unnecessary barriers to the free flow of information' - which, under the TPP, could lead to a deadlock, since countries like Malaysia and Vietnam have local content restrictions. Another cross-cutting theme that should be included in the TPP agreement concerns the role of supply chains and the importance of facilitating trade and doing business to increase the competitiveness of companies in member countries (CARNEIRO, 2014).

\section{METHODOLOGY}

The present study aims to demonstrate the possible impacts after the announcement of the exit of the United States of America from the Transpacific Partnership Agreement (TPP), mainly for Brazil. According to Gil (2008), the exploratory research provides a greater familiarity with the problem and, in the case of the exploratory research, usually takes the form of bibliographic research and case study.

With regard to technical procedures, bibliographical and documentary research was developed, based on material already elaborated, consisting mainly of scientific articles and books (GIL, 2008). Subscribe, Severino (2017) considers as a bibliographical research the one realized from the record available in previous researches, in which the researcher works from the contributions of the authors of the analytical studies contained in the texts.

Documentary research is very similar to bibliographical research. The difference lies in the nature of the sources, since the documentary research uses material that has not yet received an analytical treatment, or that can still be re-elaborated according to the objects of the research. In addition to analyzing 'first-hand' documents (archives, churches, unions, institutions, etc.), there are also those that have already been processed but may receive other interpretations, such as company reports, tables (GIL, 2008). Severino (2017) still considers as documentary research sources newspapers, photos, films, recordings and legal documents.

\section{RESULTS AND DISCUSSION}

According to Menezes et al. (2006), any economic integration in the world is an ongoing, unfinished process. Still, according to the authors, several physical, political, economic and social obstacles affect the negotiations involving the economic and commercial integration agreements. Negotiations for the TPP agreement began in 2001 with then-President George W. Bush and peaked when the agreement was signed by the foreign ministers of the member countries in February 2016, still under the mandate of Barack Obama, who celebrated with the following phrase: "The partnership allows the US - not countries like China - to write the road rules of the 21st century" (SILVA, 2016). In this way, the intention is to restrain the growing Chinese commercial influence by deliberately excluding that country.

Barbosa (2015) points out that the TPP would control 40\% of global GDP and would have a strong impact on the multilateral trading system, since its rules were created outside the WTO, setting new 
standards for international trade. In view of the purpose of this research, this multinational economic openness is contrary to the policy advocated by the current President of the United States, Donald Trump. In his presidential campaign, Trump focused on securing jobs and boosting national industry. At this point, the proposals of the transpacific agreement are divergent from the proposals of the current government, which fears a flight of industries to the countries participating in the agreement where labor is cheaper. This was a key issue for Donald Trump, on January 23, 2017, to sign the United States exit from the TPP agreement, on the grounds of avoiding job losses in his country (NINIO, 2017).

According to Fariza (2017), the announcement of the US withdrawal from the TPP, despite being expected, is a major blow to the Mexican economy and, to a lesser extent, to the other two Latin American countries signatories to the pact: Peru and Chile. In this sense, Felipe (2017) points out that Mexico intends to discuss with the United States a bilateral agreement and present what the priorities are in this new relationship. According to the author, Peru and Chile also signaled that they will seek bilateral agreements with countries that are part of the TPP, such as Japan. Corroborating, Pinto (2017) argues that the withdrawal from the United States would even have potential to render the functioning of this free trade agreement unfeasible - and that Chile and Peru would have to review their foreign trade priorities, including by reallocating their international flow of goods and services.

Pereira (2013) points out that Brazil has a limited agenda of trade agreements, is outside the megaagreements, has a commodity export agenda and presents indicators of low participation in regional / global value chains. Thus, Moreira Junior et al. (2016) indicate that in South America, ruptures in the institutional order in several countries, with Brazil and Venezuela as exponents of the moment, deepen the scenario of economic and political crisis, and hamper a project of political, economic, commercial and productive integration. On the other hand, the decision of Donald Trump benefits, in a collateral manner, the Mercosur countries, led by Brazil and Argentina, who gain time to sign new treaties and avoid being left out of the new architecture of international trade. And it leaves China in a position of great global strength (FARIZA, 2017).

Pinto (2017) points out that the uncertainties regarding the future of the TPP may represent an unique opportunity for Brazil to re-open its commercial participation at the regional level, mainly in bilateral relations with Mexico, Chile and Peru, including with increased exports of products of greater added value to these countries, one of the main challenges for the international trade in Brazil today.

The exit of the United States from the TPP could be beneficial for Brazil, considering that the formalization of the agreement would facilitate the penetration of North American agricultural products in the markets of the member countries. This premise is emphasized by Costa (2016), according to which the most affected products would be mineral and agricultural commodities. Still according to the author, the exports of these products to the member countries of the TPP are around US\$54bi and are expected to decrease by at least $3 \%$, creating a significant loss for the Brazilian economy.

According to the BBC Brasil (2017), Donald Trump's decision to withdraw from the agreement could result in benefits for Brazilian agribusiness if Brazil seizes the opportunity to negotiate with markets that will stop receiving US products under special conditions. On the other hand, if Trump's protectionist stance 
gained over his term, US-China relations could be reduced, leading to lower Chinese demand for commodities, which would have a negative effect on Brazil, a major exporter of commodities.

\section{FINAL CONSIDERATIONS}

The development of the present study provided a brief analysis of how the announcement made by US President Donald Trump regarding his country's withdrawal from the transpacific agreement could affect the other countries participating in the agreement as well as the world economy. In this sense, the study shows some impacts for Brazil when the United States of America (USA) leaves the transpacific partnership agreement (TPP).

Considering the brazilian international policy agenda, one can see that the country is isolated from the main multilateral negotiations and the formations of global and regional productive chains. It is also necessary to discuss the relationship of trade agreements to which Brazil is a party, especially Mercosur and its domestic foreign trade policies. The isolation of Brazil in relation to world trade policies is evidenced in the study of several authors such as Bayne et al. (2011), Pereira (2013), Thorstense et al. (2014), Cervo et al. (2014), Costa (2016), and Pinto (2017), a relevant fact that must be considered for possible changes in the international political and commercial agendas.

With the research, it is perceived that the exit of the USA affects the economy of several countries: some positively, as can occur in the case of Brazil; and others negatively, as in the case of Mexico. Of particular note is the approach of the United States to China, considering that one of the main goals of the americans in relation to the TPP was to isolate the chinese and to shield their entry into Asia and the south pacific. In this sense, it becomes important and necessary to be aware of any changes that take place in the economy and in the world political scenario.

Considering that the research contributed to the authors' personal, academic and professional growth, it is a current and important topic for the debate on economic and foreign policy. Like politics and economics, this subject is very unstable and can be altered at any time, and may even refute the analyzes obtained. As a suggestion of future research, it is interesting to investigate the impacts for the countries that make up the TPP agreement, based on sectoral analyzes and / or macroeconomic impacts.

\section{REFERENCES}

ALMEIDA, M. C. C. M.. Zonas de Processamento de Exportação e a Lei da Organização Mundial do Comércio. University of Brasília Law Journal, v.1, n.2, 2016.

BALDWIN, R.. Trade and industrialization after globalization's second unbundling: How building and joining a supply chain are different and why it matters. Springfield: University of Chicago Press, 2013.

BARBOSA, R.. Parceria transpacífico, liberalização competitiva. Rio de Janeiro: 2015.
BAYNE, N.; WOOLCOCK, S.. The new economic diplomacy: decision-making and negotiation in international economic relations. Farnham: Ashgate Publishing, 2011.

BBC BRASIL. British Broadcasting Corporation in Brazil. O que é o TPP, o acordo econômico entre 11 países do qual Trump retirou EUA. São Paulo: 2017.

CARNEIRO, F. L.. Parceria Trans-Pacífico: um acordo megarregional na fronteira da regulação do comércio internacional?. Brasília: IPEA, 2015. 
CERVO, A. L.; LESSA, A. C.. The fall: the international insertion of Brazil (2011-2014). Revista Brasileira de Política Internacional, v.57, n.2, 2014.

CHIARA, M.. Saída dos EUA do TPP abre janela de oportunidades. São Paulo: 2017.

COSTA, L. M.. Tratado transpacífico de livre comércio: é possível reparar os prejuízos?. GV-Executivo, v.15, n.1, p.4245, 2016.

DIAS, R.; RODRIGUES, W.. Comércio exterior. São Paulo: Atlas, 2012.

FARIZA, I.. Saída dos EUA do TPP fere México, mas pode ser positiva para o Mercosul. Madrid: 2017.

FELIPE, L.. Com saída dos EUA do Transpacífico, países se articulam para negociações. Londrina: 2017.

FRANCISCO, W. C.. Acordos internacionais. Goiânia: 2010.

GARCIA, E. V.. Cronologia das relações internacionais do Brasil. Rio de Janeiro: Contraponto, 2005.

GIL, A. C.. Como elaborar projetos de pesquisa. 4 ed. São Paulo: Atlas, 2008.

LINS, H. N.. Parceria Trans-Pacífico: Novas Geometrias no Capitalismo Global. Contexto Internacional, v.36, n.2, p.623, 2014.

MENEZES, A. M.; PENNA FILHO, P.. (2006). Integração regional: os blocos econômicos nas relações internacionais. Amsterdã: Elsevier, 2006.

MOREIRA JUNIOR, H.; MENEZES, R. G.. Apresentação do dossiê: economia política internacional de sul a norte: desafios para a agenda global em um contexto de crises e instabilidade. Monções: Revista de Relações Internacionais da UFGD, v.5, n.9, p.1-8, 2016.

NINIO, M.. Por decreto, Trump retira EUA da Parceria Transpacífico. São Paulo: 2017.
PEREIRA, L. B. V.. Mudanças no cenário internacional e a política de comércio exterior do Brasil. Cadernos do Desenvolvimento Fluminense, n.9, p.25-37, 2013.

PINTO, H. S.. Novo governo na Casa Branca: possíveis consequências econômicas para o Brasil. Brasília: 2017.

RÊGO, E. C. L.. Do Gatt à OMC: o que mudou, como funciona e para onde caminha o Sistema Multilateral de Comércio. Brasília: 1996.

SANT'ANNA, L.. Novo pacto multilateral no Pacífico é chance para o Brasil. São Paulo: 2017.

SCHOTT, J.; KOTSCHWAR, B.; MUIR, J.. Understanding the Trans-Pacific Partnership. Washington: 2013.

SEVERINO, A. J.. Metodologia do trabalho científico. São Paulo: Cortez, 2017

SILVA, D. M.. A expansão para o Oeste: a Parceria Transpacífica sob a perspectiva dos Estados Unidos. São Paulo: UNESP, 2016.

SIMÕES, R. C.; MORINI, C. A ordem econômica mundial: Considerações sobre a formação de blocos econômicos e o Mercosul. Revista Impulso, n.31, 2002.

TAQUES, F. H.; CAVALCANTE, H. H.; MONTEIRO, M. B.. Fluxo de comércio entre o Brasil e os demais países dos BRICS. Revista Economia e Desenvolvimento, v.14, n.2, 2016.

THORSTENSEN, V.; FERRAZ, L. O isolamento do Brasil em relação aos acordos e mega-acordos comerciais. Brasília: IPEA, 2014.

USTR. United States Trade Representative. Free Trade Agreements. Washington: 2017.

VALÉRIO, M. A. G.. Organização Mundial do Comércio. Revista de Informação Legislativa, p.121, 2009.

A CBPC - Companhia Brasileira de Produção Científica (CNPJ: 11.221.422/0001-03) detém os direitos materiais desta publicação. Os direitos referem-se à publicação do trabalho em qualquer parte do mundo, incluindo os direitos às renovações, expansões e disseminações da contribuição, bem como outros direitos subsidiários. Todos os trabalhos publicados eletronicamente poderão posteriormente ser publicados em coletâneas impressas sob coordenação da Sustenere Publishing, da Companhia Brasileira de Produção Científica e seus parceiros autorizados. Os (as) autores (as) preservam os direitos autorais, mas não têm permissão para a publicação da contribuição em outro meio, impresso ou digital, em português ou em tradução. 